\title{
THE RELATIONSHIP BETWEEN HOUSEHOLD CONSUMPTION EXPENDITURE AND VARIOUS FACTORS
}

\author{
Maire Honkanen \\ Department of Household Economics, University of Helsinki
}

Received November 18, 1967

\section{Introduction}

The level and structure of consumption have been found dependent on the income available to the consumer, his preferences, and the prices of the commodities on the market (cf. e.g. WALlBERG 1965, p. 29). Of these, the economic variables, particularly the incomes and the prices, lend themselves to objective measurement, while the assesment of many preference effects is rather subjective and difficult. In recent years, special attention has often been paid to the fact that economic factors alone do not explain the behavior of the consumer, which is, in fact, greatly influenced by other factors in the consumer's living conditions. - Until recently, research in Finland has concentrated on the variations in consumption in relation to income, prices and various other factors, chiefly in order to construct demand functions (TöRnQvist 1941, KaARLehto 1961, Korpelainen 1967). Closer studies on consumption variations and the factors affecting them, from the point of view of private economy - with the exception of the official consumption investigations carried out at irregular intervals during the last sixty years - have received little attention. The rural consumption investigation carried out in 1959/60 (OSF XXXII:24) yielded data which enabled studies on the relationship between expenditure on food and especially the number of children. This brought up the question of what were the variables of primary importance in determining the other items of consumption. The present study likewise makes use of the data on the individual households collected for the rural consumption investigation. The data was collected from 570 farming households and 312 households, where the income came from salaries, selected from various parts of the country (see OSF XXXII:24, pp. 8-9). (The slightly smaller number of households in this paper as compared to the rural 
consumption investigation is due to the omission of the so-called duplicate cards of the wage earners (cf. OSF XXXII:24, p. 9) and the incomplete or incorrectly punched cards, when the data were transferred from the cards to tapes.) - A grant from the Finnish Association of Agricultural Graduate has enabled me to carry out the investigation and to process the data.

The income of a consumer is composed of permanent and incidental earnings; the latter may be either unexpected or expected. The income at the disposal of the consumer is the sum left after tax deductions. He may spend this income on consumption in toto or in part, saving the rest. A consumption investigation does not, however, always analyse income in sufficient detail (cf. for example OSF XXXII:24, pp. $32-33$ ) to enable the classification of the consumers according to their income. Total consumption expenditure is generally used as the basis for the estimates (Bentzel 1957, p. 109, Prais and Houthakker 1955, pp. 3-81). The difference between total consumption expenditure and the available income is mainly composed of savings and paid interests. If the inclination to save (consume) is about equal in the various income classes, not considering the savings does not essentially affect the results. This problem has not, however, been fully solved (FERBER 1962, p. 24). The absolute as well as relative expenditures on interest, on the other hand, were rather small in for instance the households selected for the rural consumption investigation and consequently not of decisive significance in the calculation of the final results. Interest expenses and taxes have, however, been added to the total consumption expenditure in the rural consumption investigation (OSF XXXII:24, p. 16) in determining the expenditure class of the household, which has also in this paper been used as an index of the household income.

It should be noted, however, that owing to the method of compiling the required information, the total expenditure class of each household has been computed on the basis of one month's expenditure. If the expenditure happened to be exceptionally high or low (e.g. because of large acquisitions or use of food stores) the household might fall into an expenditure class not representative of the annual mean. The fact that tax payments are not equally distributed among the months, may have had a similar effect especially in farming households. It was impossible for practical reasons, however, to remedy this situation. - The nature of the available data also posed some restrictions to the variables explaining the dependence of the consumption expenditure.

Consumer's preference is a relatively comprehensive concept which includes the structure and living conditions of a household unit and various outside influences that it is subject to (WALLBERG 1965, p. 35). The factors pertaining to the preferences can be classified as demographic, socio-economic, and social-psychological. - In the present study the factors indicating consumer preferences are the number of children, the age of the head of the household, the duration of the marriage, the working of the housewife outside the home and the industrialisation degree of the locality. It is also possible to regard the size of the family either as a social or an economic factor.

When an investigation is carried out during a fixed period of time, the effect of the prices is noticeable chiefly in comparisons between geographic regions. The 
structure of expenditure may also vary among regions. Since the data used in this study has been collected during a period of twelve months, possible seasonal price fluctuations may affect the consumption expenditure, which is also affected by the changes in the amounts of commodities used during different periods. It was not, however, possible to separate the effects of these components in the data available. The effect of seasonal chenges on the consumption expenditure is consequently an cutcome of fluctuations in prices and in consumption quantities.

The expenses of farming households and wage-earner households have been examined separately since significant differences in consumption have been established for these (cf. e.g. HonkAnen 1967 a). The amount of data was rather small (OSF XXXII:24, pp. 16-17, 24); therefore it was not considered appropriate to include a more detailed social classification in the analysis. On the other hand, relatively large-scale social groupirg did not appear have significance within the various income or expenditure groups.

\section{Research unit}

In studies of the consumption of a certain commodity or commodity group in respect to which consumers may be converted into units of equal value, these are generally called consumer units (c.u.). On one scale it is impossible to describe the differences in the needs of persons of different ages and different sexes. For these reasons, for instance Lydall (1955) has used what he calls an "earning unit" composed of persons making joint use of an income. This unit is, with certain exceptions, the same as a household unit (MAdSEN 1964, s. 9). Gredal (1966, p. $35)$ have called attention specifically to the significance of the family as a research unit.

In this paper, various commodity groups are studied in respect to which the consumption requirements of persons of different ages and sexes may vary. Some of the commodities are also used jointly within the same household unit (e.g. furniture and household supplies). The total amount of consumption is nevertheless dependent on the income available to each household (cf. OSF XXXII:24, pp. $14-15)$. For these reasons the household was chosen as the research unit. v.HofsTEN (1960, p. 146) also mentions that a similar unit is used in studies concerning household budgets particularly because the members of the household jointly participate in a large part of the consumption.

\section{The relationship between consumption expenditure and various factors}

To get an idea of the relationships between the various expense items and the factors that influence them, correlation matrices including all the variables were calculated. It was found, that with the several expense groups exhibited a statistically significant correlations. Among the different expense groups the other expenditure was correlated closest with the expenditure class $(r=0.88)$. The seven expenditure groups (tables 1 and 2) were selected for closer study (they composed $98.1 \%$ of the consumption expenses in farming and $98.2 \%$ in wage-earner house- 
holds; expenditure on tobacco and alcoholic beverages was the only group not included).

The variations in the relative shares of these groups in the total expenditure were studied by "stepwise" regression analysis. On the basis of precomputed correlations, the following variables were introduced into the regression in order: the expenditure class as a linear (coefficient =a1), logarithmic (a2) and quadratic term (a3), and the consumer unit variable (a4). After all these had been considered, the program proceeded to test their significance, and it was possible to drop one or several of the variables. The other variables were introduced in the stepwise order (X1-X8 are dummy variables, values 0 or 1 ; cf. OSF XXXII:24, pp. 15-19):

South Finland

Central Finland

North Finland

April-June

July-September

October-December

housewife not working outside

$\times 1$
$\times 2$
$\times 3$
$\times 4$
$\times 5$
$\times 6$
$\times 7$

housewife working fulltime outside industrialisation degree of commune duration of marriage number of children number of consumer units age of head of household expenditure class
X 8

$\mathrm{X} 9$

$\mathrm{X} 10$

$\mathrm{X} 11$

$\mathrm{X} 12$

$\mathrm{X} 13$

$\mathrm{X} 14$

It is evident that some factors, for instance those indicating geographic regions, fall within the same category. In addition to these correlations, some other correlations were detected between the independent variables. The correlation between the number of children and the number of consumer units was quite close (farmers $\mathrm{r}=0.70$ and wage earners $\mathrm{r}=0.66)$. The age of the head of the household and the duration of marriage were also correlated (farmers $r=0.48$ and wage earners $\mathrm{r}=0.53)$. On the other hand there was a negative correlation between the age of the head of the household and the number of children (farmers $r=-0.34$ and wage earners $\mathrm{r}=-0.47$ ). The expenditure class was correlated closest with the number of consumer units (farmers $r=0.55$ and wage earners $r=0.53$ ). It should be noted that in farmer families the relationship between the housewife's full-time paid work (outside the home) and the expenditure class was negligible $(r=0.09)$, while in wage-earner families, the correlation was rather close $(r=0.35)$.

In most cases the program dropped the logarithmic expenditure term in the farmer group, which nevertheless satisfactorily explained dwelling and other expenditures as well as expenditure on food. For the wage earners, the logarithmic transformation of the expenditure term proved the best. Wage earners' expenditure on food and, to a certain extent, on clothing and housing depended above all on the number of the consumer units.

The relative food expenditure in farmer households was primarily affected by the logarithmic and the quadratic terms of the expenditure class. Since both terms are almost equal in significance, neither can be neglected. The first and second degree terms almost cancel out each other for the wage earners and the logarithmic term becomes most significant. In wage-earner households $41.5 \%$ of the variation in food expenditure was accounted for by the amount of expenditure and the number of consumer units, while the corresponding figure for farmers was only $30.3 \%$. Among the optional variables, the expenditure on food was above all related to the period of collecting the information. (It should be noted that each of the households 
in the investigation recorded their consumption expenditure for one calendar month.) An earlier analysis of food expenditure (HoNKANEN $1967 \mathrm{~b}$ ) showed variation by the season of investigation in a number of foods. - Since the obligatory variables seemed able to explain the expenditure on food in terms of money relatively well (farmers $72.0 \%$, wage earners $77.4 \%$ ) the model was further developed to find out the correlations with the monetary expenditures.

The part of the total spent on d welling was far less related to fluctuations in total expenditure than was the amount spent on food. For the farmers this is understandable as they are generally tied to the buildings on the farm and these are seldom enlarged in proportion to increases in the number of consumer units of the household. The obligatory variables explained only $1.5 \%$ of the variations. In wage-earner households, total expenditure and the number of consumer units are related to dwelling expenses somewhat more closely than in farmer households. Here, also, the logarithmic form of the expenditure class variable was the best. It is worth noting that the relative expenses on dwelling in wage-earner households decrease somewhat, when the number of consumer units increases. Although it has been established in various contexts that the present-day consumer plans, not only the expenditure in his budget, but also the items of income (Katona 1960, pp. $29-30$, SAARSALMI 1966, p. 164), an increase in family size generally necessitates a drop in some aspects of the standard of living. KAARLEHTO (1961, p. 20) even maintains - basing his opinion on the data of the 1955/56 consumption investigation - that there is a linear negative correlation between the average level of consumption per person and family size. It is evident that with increased expenditure on for instance food and clothing the family often has to be content with more crowded living conditions.

Expenditure on clothing constituted $10.4 \%$ of the total expenditure in farmer households and $11.1 \%$ in wage-earner households. In the former group, the variations in the relative clothing expenditure were related to a rather small extent with the expenditure class and the number of consumer units.The introduction of the optional independent variables into the equation raised the percentage of determination; still, only $9.2 \%$ of the variations in expenditure were explained by the model. It should be noted that increases in the number of consumer units increased clothing expenditure in relation to the total. For the wage earners, the expenditure class and the number of consumer units explained the variations in relative clothing expenditure somewhat better than for the farmers. The relative clothing expenditure of the wage earners decreased with an increase in the number of consumer units, a tendency which has already been established for expenditure on dwelling. The wageearner household's housewife's full-time paid work outside the home, on the contrary, increased the relative clothing expenses. - The model was more efficient in explaining the variation in clothing expenditure in terms of money (farmers $33.1 \%$ and wage earners $34.8 \%$ ) than the variations in the relative expenditure.

Only a small part of the variations in the rather small relative expenditure on furniture and household supplies were explained by the model. This was the case also for expenditure on household $\mathrm{machines}$, which are included in these expenses. BENTzEL et.al. $(1957$, p. 71$)$ have, in fact, noted that 
it is possible to analyse the demand for large commodity groups by a relatively limited number of variables, since it is generally possible to find substitutes in a group. When single commodities are considered, people's preferences vary greatly. This again makes it more difficult to find regularities.

The model also provided no explanation to the rather small relative expenditure on $\mathrm{lin}$ e n a n d b e d d ing (farmers $0.7 \%$ and wage earners $0.8 \%$ ). A drop in the relative expenditure following an increase in the number of consumer units was, however, evident also here. This may in certain cases be due to the reasons discussed previously in connection with the expenditure on dwelling. It is, however, also conceivable that a family at a later stage may not have the same need to acquire linen and bedding as a newly established family (cf. MADSEN 1964, p. 9-17).

$\mathrm{O}$ ther expendit u re, composed of a number of different items, was about a fifth of the total expenses in both farmer and wage-earner households. The model explained $18.9 \%$ of the other expense variation for farmers and $22.7 \%$ for wage earners.

The results showed that the logarithmic and second degree expenditure class variables explained the share of the other expenditure. For the farmers, the model also included the linear term, which almost cancelled the second degree one as a corrective term. Considering the last for the farmers, the increase of other expenditure thus followed the rise in the expenditure class on the logarithmic scale. Attention is also drawn to the fact that an increase in the number of consumer units caused a drop in the other relative expenditure both for farmers and wage earners. The degree of industrialisation of the locality also reduced the share of other expenditure in farming households, which may be attributable to the fact that school expenditure goes down because of possibly better school conditions in an industrialised locality as compared with a predominantly farming locality. In farming households, on the other hand, the housewife's full-time paid work outside the home increased the other expenditure.

\section{The relationship of consumption expenditure in terms of money to various factors}

It can be seen that in several instances the expenditure class and the number of consumer units explained best the variations in the relative expenditure groups. Therefore, the equation interpreting the variation in monetary consumption expenditure was further developed by e.g. including an $\mathrm{X} 12 \cdot \mathrm{X} 14$ variable. The equation was further supplemented by the variables $\log (\mathrm{X} 14+1), \mathrm{X} \mathrm{14}^{2}, \mathrm{X} 14^{3}$, $\mathrm{X} 12 \cdot \mathrm{X} 14^{2}, \log \mathrm{X} 9, \log (\mathrm{X} 11+1), \mathrm{X} \mathrm{11^{2 }}, \mathrm{X} 11 \cdot \mathrm{X} 14$. All variables were introduced into the regression in the stepwise order. The model equations are given in tables 3 and 4 . The results showed that the term $\times 12 \cdot \mathrm{X} 14$ explained the monetary f o o d expenditure variations fairly well:

$\begin{array}{llc} & & \% \text { explained } \\ \text { farmers } & \mathrm{R}=143.43+5.58 \cdot \times 12 \cdot \times 14 & 69.7 \\ \text { wage earners } & \mathrm{R}=98.90+6.80 \times 12 \cdot \times 14 & 75.4\end{array}$


The relationships between the food expenditure, the total expenditure and the number of consumer units - for the wage earners the term $-0.483 \mathrm{X} 12 \cdot \mathrm{X} 14^{2}$ was added to the equation above; the equation explained $77.4 \%$ of the variation in this case - are shown in tables 5 and 6 .

As we compare the relationships between the food expenditures of the farmers and the wage earners, and the expenditure classes and the numbers of consumer units, it can be seen that a rise in the expenditure class and the number of consumer units increases spending on food less in farming households than in those of wage earners. It should be kept in mind that the farmers' food expenses were already higher than that of the wage earners in the lowest expenditure classes. The differences thus even off with increases in the expenditure class and the size of the family. Since July-September stood out rather clearly in the model, particularly for the farmers but also the wage earners, the expenditure relationships were separately studied for this period. The results indicate that the July-September food expenditure does not grow as steeply as the mean annual food expenditure in the highest income (expenditure) classes. It should be noted that the food expenditure in farming households was almost $15 \%$ higher in July-September than during the rest of the year.

As has already been seen, the dwelling expenditure is rather static within a farming household, while there may be considerable differences between households. It should also be kept in mind that in the data, the farmers' dwelling expenditure was estimated more often than that of wage earners (cf. OSF XXXII: 24, p. 11). The results indicate that the farmers' dwelling expenditure was primarily dependent on the quadratic term of the expenditure class, i.e. that dwelling expenditure rose at a slower rate in the lower classes, while the rate increased when the highest classes were reached. An increase in the number of consumer units slowed down the upward trend in this expenditure in terms of money. This expenditure was at its lowest in July-September, partly due to the small cost of heating during this period. The model explained the expenditure in terms of money somewhat better $(14.4 \%)$ than the earlier model (table 2). The model explained $24.7 \%$ of the dwelling expenditure of the wage earners; thus the wage-earners' pattern proved to be more efficient than that for the farmers. It should be noted that the wage-earners' dwelling expenditure was best explained by the third degree expenditure class variable, the product of the number of consumer units and the quadratic expenditure class variable as well as the product variable of the number of children and the expenditure class. The first of these mainly shows that the dwelling expenditure in the lowest expenditure classes grew little from a low-expenditure class to the next, the rate of growth being much larger in the highest expenditure classes. An increase in the number of consumer units had a retarding effect on the rate of growth.

The determination percentage for clothing expenditure rises a bit for both farmers and wage earners, when the variations are studied by the developed model, as compared with using the original model in tables 1 and 2 . In both household types it is found that clothing expenditure increases are related to the quadratic expenditure class variable. - Especially in the wage-earner households, but also in the farming households, the housewife's full-time paid work outside the home essen- 
tially increased monetary clothing expenditure, a tendency which was also seen in the relative expenditure of wage-earner households.

Expenditure on furniture and household supplies was also somewhat better explained by the second model than the original one, although the percentage of determination was still relatively low $(9.4 \%)$ for the farmers. For the wage earners, the percentage rose to $22.7 \%$. The third degree expenditure class variable, and the product of the number of consumer units and the quadratic expenditure class variable provided the best explanation of the variation in this group, like for the dwelling expenditure.

The acquisition of $\mathrm{h}$ ou se hold $\mathrm{mach}$ in es was so limited in the farmer households studied that no regular variations could be observed. The model also explained relatively little of the variations for the wage earners, but it should be noted that these expenses were best explained by the third degree expenditure class variable. This was suggested by for instance amounts spent on household machines, in the data grouped into three expenditure classes. Mainly for this reason this variable was included in the model; it had also turned out provide the best explanation — as has been seen - for the variations in the dwelling, furniture and household supplies, and other expenditure of the farmers.

The relatively large variation, as compared to the mean in be d d in g a n d $\mathrm{l}$ in e $\mathrm{n}$ expenses was explained only to a limited extent (farmers $6.8 \%$ and wageearners $8.1 \%$ ). In farming households, the amount of this expenditure was related to the expenditure class in much the same way as clothing expenses. The equation also included quite a number of other variables.

The other expenditure group has been considered as a whole in this study, mainly as an experiment. It was assumed a priori that the data available did not enable closer study of the many different kinds of expense items it includes, each one of which would have been worth an independent study. Some information as to which factors the expense items of the group were chiefly related was, however, desired. Therefore this group was tested by the same equations as the other expenditure groups. The other expenditure of the farming households seemed to be related to the expenditure class in a similar way as the expenditure on furniture and household supplies. The developed model was somewhat more efficient in explaining the variation in this group than the original one. In wage-earner households, also, the relationship of these expenses was not linear, but rather parabolic, to increases in income (expenditure class). This variable alone explained nearly one half $(49.4 \%)$ of the variations in this expenditure. The contribution of several additional factors to the degree of determination of the model was relatively small.

\section{Discussion}

The results indicated that, with the exception of the food expenses, all expense groups were most closely correlated with the expenditure class, and even increased in relation to the second or third degree of the expenditure class. In most cases, the factor keeping expenses increase down was the number of consumer units or an increase in the number of children. 
The food expenditure was the least elastic; it increased in a linear relationship to the expenditure class and the number of consumer units. Clothing expenditure, the dwelling expenditure of the farmers, and the other expenditure of the wage earners were more elastic than the food expenses. The relationship of the variations in their level with the expenditure classes fits a parabolic curve. The most elastic, in relation to the income, were the dwelling expenditure variable for the rural wage earners, and the furniture and household supplies expenditure variable for the farmers and the wage earners. The other expenditure group for the farmers also exhibited considerable elasticity in relation to income (expenditure class). These expense groups were most closely correlated to third degree increase of the expenditure class.

\section{$S u m m a r y$}

The purpose of this study has been to elucidate the relationship between various factors and household consumption expenditure. The data, collected by households, are from the rural consumption investigation carried out in 1959/60.

The data were studied in two separate groups, farming households and wageearner households. The research unit was a household.

The seven different expenditure groups (tables 1 and 2) were studied in detail and the variations in their share of the total expenditure were studied by stepwise regression analysis.

The equations developed for studying the monetary consumption expenditure are given in tables 3 and 4 .

It is notable that the third degree function of the expenditure class rise gave the best explanation for the variations in some expense groups for all these households. Of the variations in the other expenditure group for the wage earners, almost a half were d etermined by the parabolic function of the increase in expenditure alone. In explain $i_{n}$ the variations in the different expenditure groups, the models given in tables 3 and 4 proved somewhat more efficient than the original models (tables 1 and 2). It must be kept in mind, however, that the data on many of the expenditure groups were rather limited in both an absolute and a relative sense. Regularities that would explain the expenditure variations were not provided by the independent variables for all relationships. It should also be kept in mind that the results are based on data from each household for consumption expenditure for a period of one month. The available data also imposed certain restrictions on the variables tested for their relationships with the consumption expenditure. 


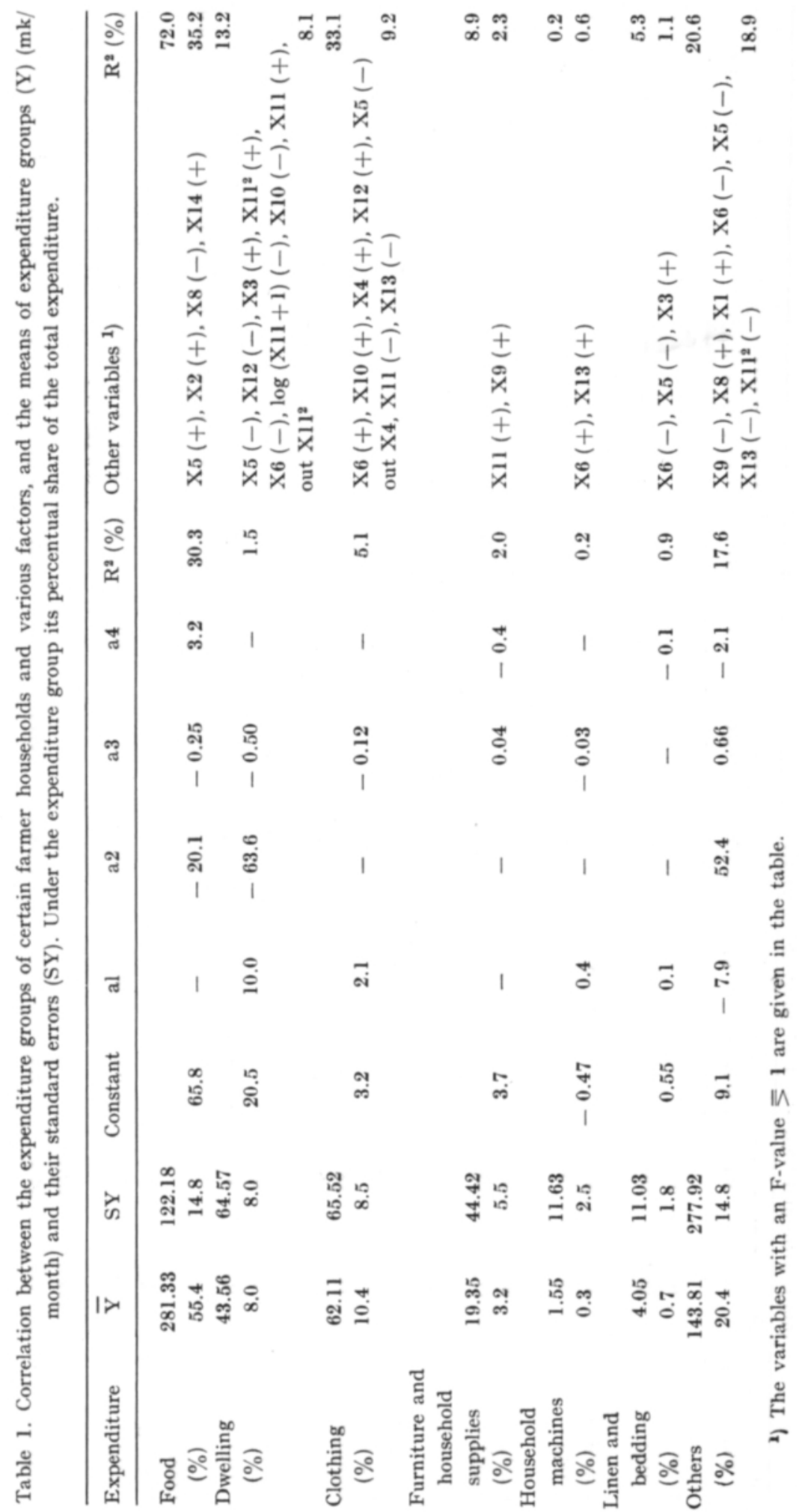




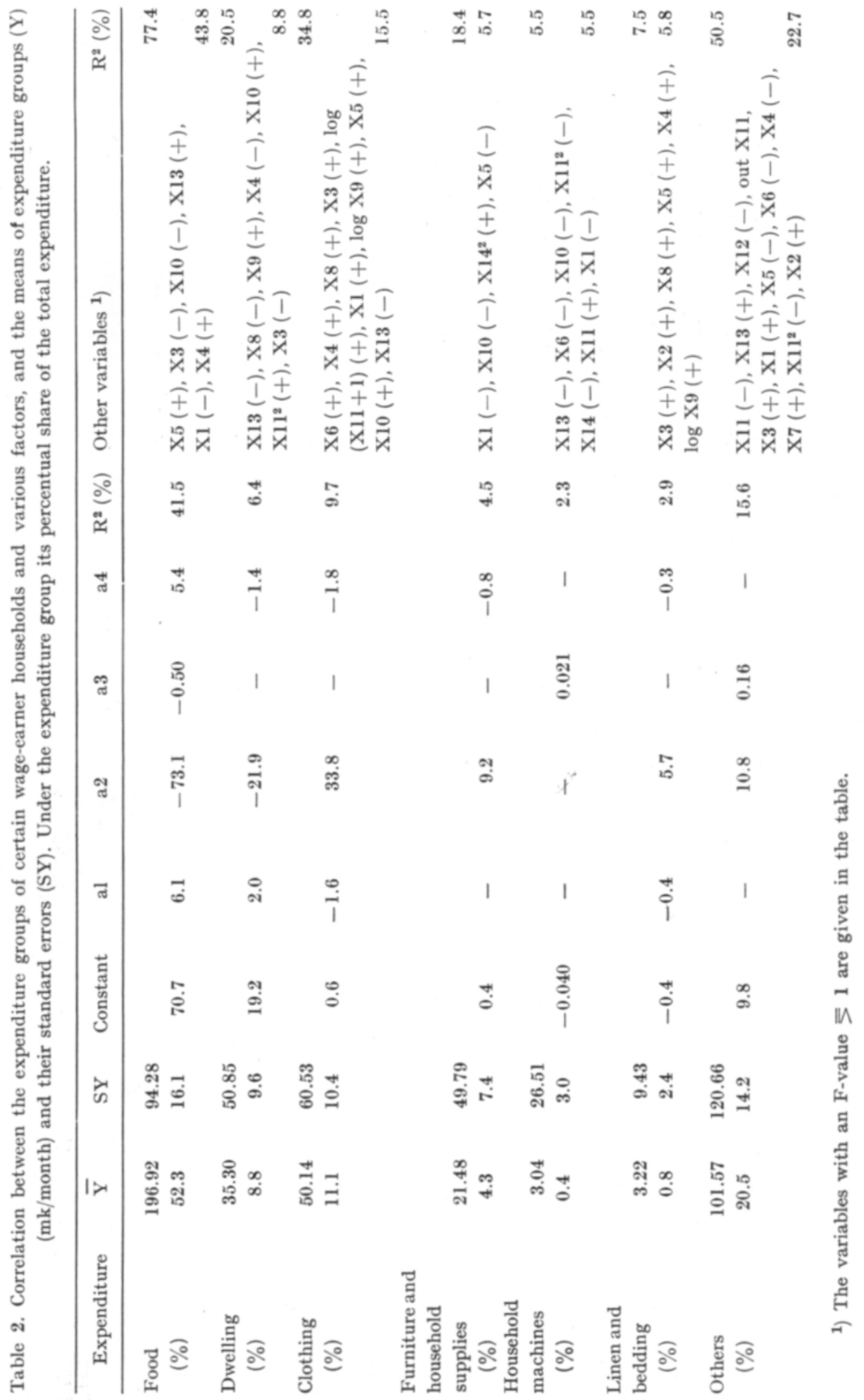




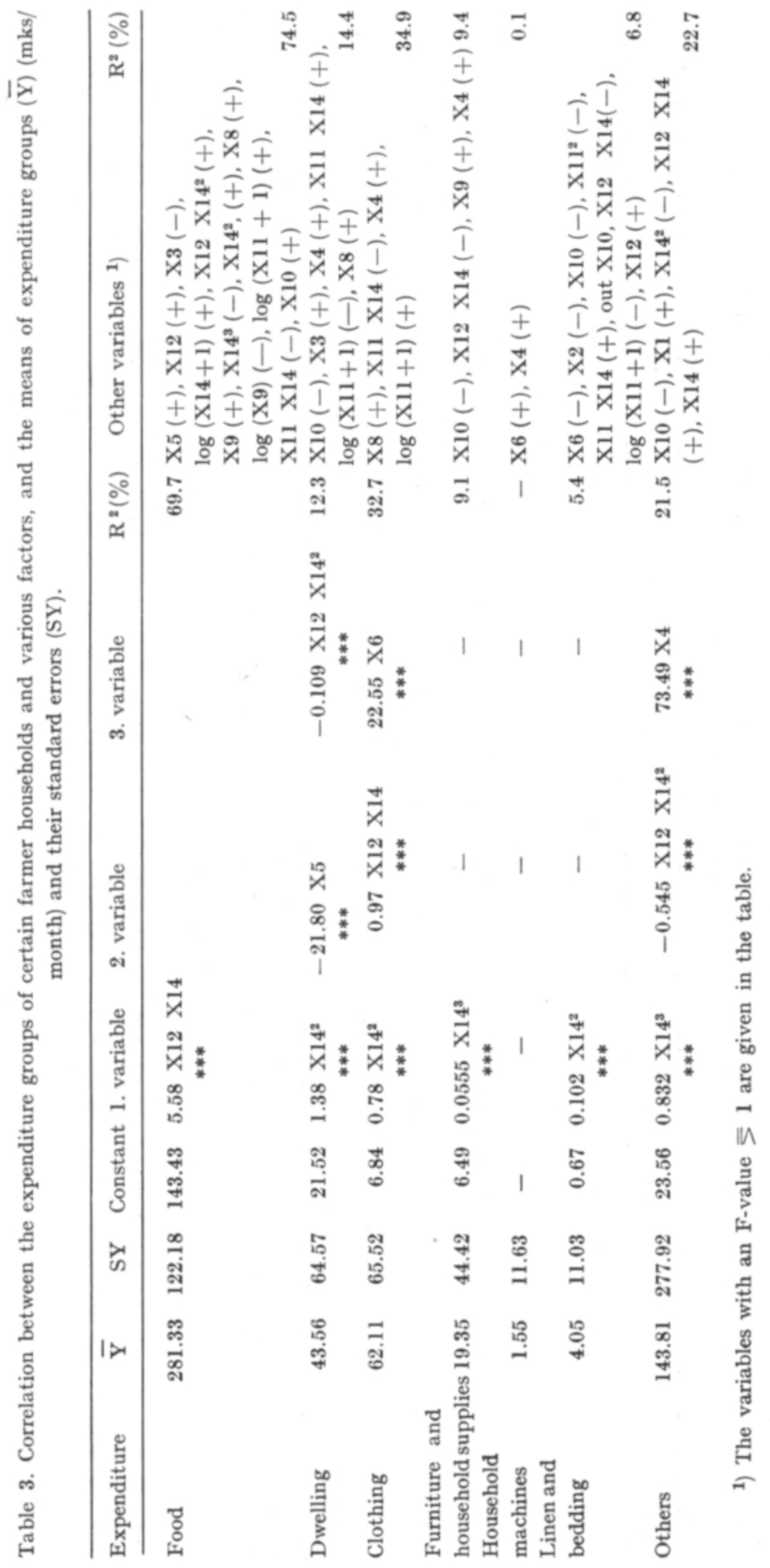




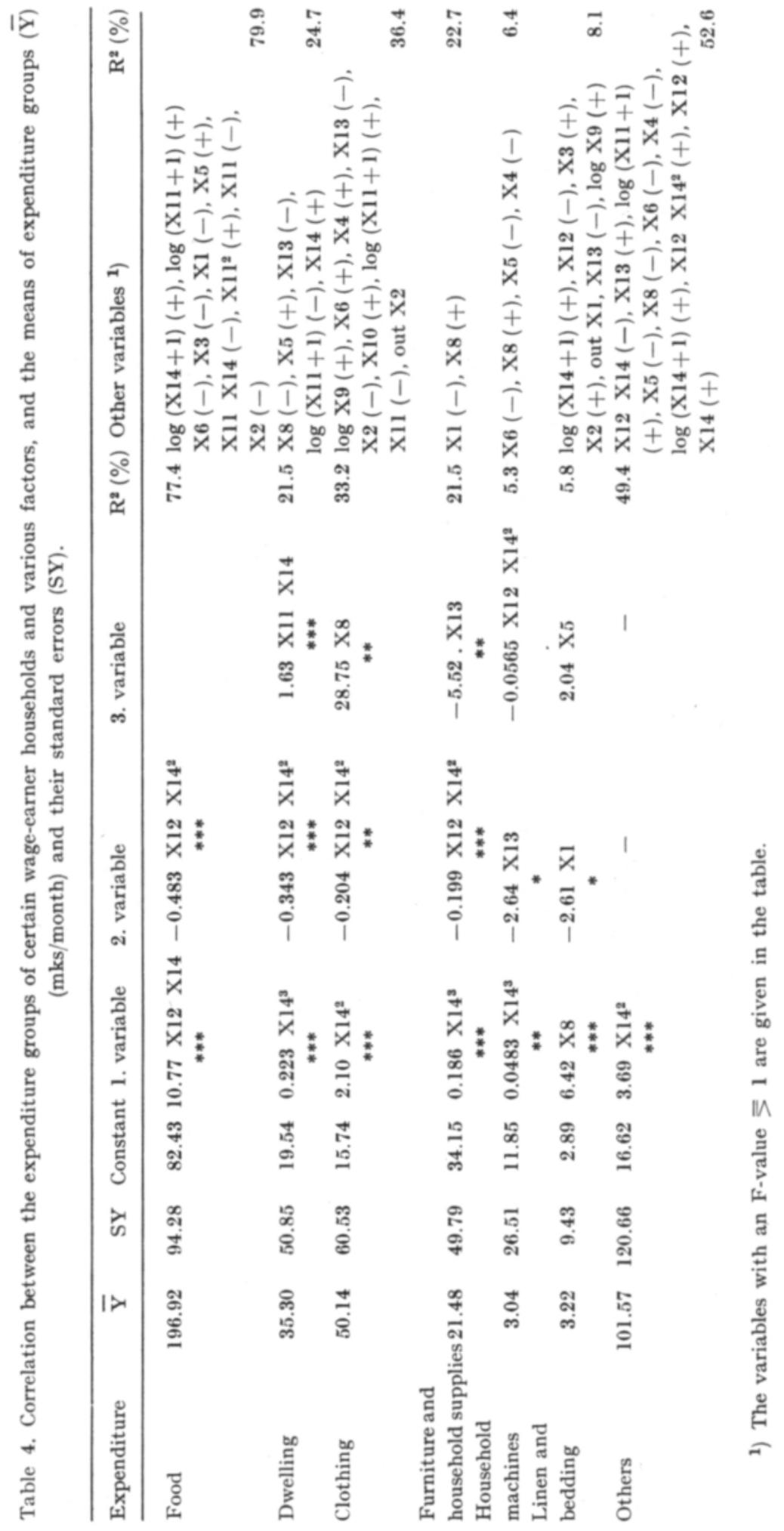


Table 5. Correlation between the food expenditure of farmer households, and expenditure class and number of consumer units.

expenditure class

\begin{tabular}{|c|c|c|c|c|c|c|c|c|}
\hline 9 & 1.35 & 1.53 & 1.70 & 1.88 & 2.05 & 2.23 & 2.40 & 2.58 \\
\hline 8 & 1.31 & 1.49 & 1.62 & 1.78 & 1.93 & 2.10 & 2.24 & 2.40 \\
\hline 7 & 1.27 & 1.41 & 1.54 & 1.68 & 1.82 & 1.95 & 2.10 & 2.23 \\
\hline 6 & 1.23 & 1.35 & 1.49 & 1.58 & 1.70 & 1.82 & 1.93 & 2.05 \\
\hline 5 & 1.19 & 1.29 & 1.39 & 1.49 & 1.58 & 1.68 & 1.78 & 1.88 \\
\hline 4 & 1.16 & 1.23 & 1.31 & 1.39 & 1.49 & 1.54 & 1.62 & 1.70 \\
\hline 3 & 1.12 & 1.18 & 1.23 & 1.29 & 1.35 & 1.41 & 1.47 & 1.53 \\
\hline 2 & 1.08 & 1.12 & 1.16 & 1.19 & 1.23 & 1.27 & 1.31 & 1.35 \\
\hline 1 & 1.04 & 1.06 & 1.08 & 1.10 & 1.12 & 1.14 & 1.16 & 1.18 \\
\hline 0 & 1.00 & 1.00 & 1.00 & 1.00 & 1.00 & 1.00 & 1.60 & 1.00 \\
\hline & 1 & 1.5 & 2 & 2.5 & 3 & $\mathbf{3 . 5}$ & 4 & 4.5 \\
\hline
\end{tabular}

Table 6. Correlation between the food expenditure of wage-earner households, and expenditure class and number of consumer units.

expenditure class

\begin{tabular}{|c|c|c|c|c|c|c|c|c|}
\hline 9 & 1.70 & 2.05 & 2.40 & 2.75 & 3.10 & 3.45 & 3.81 & 4.16 \\
\hline 8 & 1.67 & 2.01 & 2.34 & 2.68 & 3.01 & 3.35 & 3.68 & 4.02 \\
\hline 7 & 1.63 & 1.94 & 2.26 & 2.57 & 2.88 & 3.20 & 3.51 & 3.82 \\
\hline 6 & 1.57 & 1.86 & 2.15 & 2.43 & 2.72 & 3.01 & 3.29 & 3.58 \\
\hline 5 & 1.51 & 1.76 & 2.01 & 2.27 & 2.52 & 2.77 & 3.03 & 3.28 \\
\hline 4 & 1.43 & 1.64 & 1.86 & 2.07 & 2.29 & 2.50 & 2.72 & 2.93 \\
\hline 3 & 1.34 & 1.51 & 1.68 & 1.85 & 2.18 & 2.19 & 2.36 & 2.53 \\
\hline 2 & 1.24 & 1.36 & 1.48 & 1.59 & 1.71 & 1.83 & 1.95 & 2.07 \\
\hline 1 & 1.12 & 1.19 & 1.25 & 1.31 & 1.37 & 1.44 & 1.50 & 1.56 \\
\hline 0 & 1.00 & 1.00 & 1.00 & 1.00 & 1.00 & 1.00 & 1.00 & 1.00 \\
\hline & 1 & 1.5 & 2 & 2.5 & 3 & 3.5 & 4 & 4.5 \\
\hline
\end{tabular}




\title{
REFERENCES
}

Bentzel, R. et al. 1957. Den privata konsumtion i Sverige 1931-65. XVI + 475 p. Stockholm.

FERBER, R. 1962. Research on household behavior. Am. Econ. Review LII, 1: 19-63.

GREDAL, K. 1966. Moderne forbrugeres motiver og adfærd. 143 p. København.

v. Hofsten, E. 1965. Registrering och tolkning av konsumtionsdata. Konsumtionen i sociologisk belysning, p. 143-154. Stockholm.

Honkanen, M. 1967 a. Lasten lukumäärän vaikutus ravintomenoihin. Summary: The relationship between the number of children and food expenditure. Yearb. popul. res. Finl. 1967-1968. Repr. 21 p.

_- 1967 b. Maanviljelijä- ja palkansaajaruokakuntien ravintomenojen riippuvuus eri tekijöistä. Summary: The relationship between food expenditure and various factors in farmer and wageearner households in Finland. J. scient. agr. soc. Finl. 40. Repr. 12.

KAARLEHTO, P. 1961. Tulotason vaikutuksesta elintarvikemenoihin ja kulutusmääriin. Summary:Income elasticity of food expenditure and consumption. Ibid. 33,1: 17-31.

Katona, G. 1960. The powerful consumer. IX +276 s. New York.

KoRPElainen, L. 1967 Tutkimus kestokulutushyödykkeiden kysynnästä Suomessa vuosina 19481964. S. pankin tal. tiet. tutk.1. julk. B: 26: 1-139.

Lydall, H. F. 1955. British incomes and savings. Oxford Univ. Inst. Statist. monographs 5.

Madsen, B. 1964. Familiens økonomiske livsløb. 230 p. København.

Official Statistics of Finland (OSF) XXXII: 24 1962. Rural consumption investigation 1959/60.

Prais, S. J. \& Houthakker, H. S. 1955. The analysis of family budgets. XX + 372 p. Cambridge.

SAARSALMI, M. 1966. Suomalaisen kuluttajan varainkäytöstä. Liiketal.tiet. tutk.1. monisteita 18, X + 247 p.

TörnQvist, L. 1941. Arvostelu H. Woldin teoksesta „Efterfrågan pá jordbruksprodukter och dess känslighet för pris- och inkomstförändringarı. Ekon. Tidskr. 2.

WALLBERG, U. 1965. Ekonomiska aspekter på konsumtionsbeteendet. Konsumtionen i sociologisk belysning, pp. 28-37. Stockholm.

\section{SELOST U S}

\section{KOTITALOUDEN KULUTUSMENOJEN RIIPPUVUUS ERI TEKIJÖISTÄ}

\author{
MAIRE HONKANEN
}

\section{Helsingin yliopiston kodin taloustieteen laitos.}

Tutkimuksen tarkoituksena on ollut selvittää eri tekijöiden vaikutusta kotitalouden kulutusmenoihin. Aineistona on käytetty vv. 1959/60 suoritetun maaseudun kulutustutkimuksen ruokakunnittaisia tietoja.

Aineisto käsiteltiin kahtena erillisenä ryhmänä, joista toisen muodostivat maanviljelijäruokakunnat ja toisen palkansaajaruokakunnat.

Lähemmän tarkastelun kohteeksi valittiin seitsemän menoryhmää (taul. 1 ja 2). Mainittujen menoryhmien suhteellisen osuuden vaihteluita kokonaismenoista tutkittiin stepwise-regressioanalyysin avulla. Ohjelmaan sisällytettiin pakollisina selittäjinä menoluokka lineaarisena, logaritmisena ja toisen asteen terminä sekä kuluttajayksikkömäärää osoittava selittäjä mainitussa järjestyksessä. Ohjelma saattoi kuitenkin kaikkien pakollisten termien mukaantulon jälkeen poistaa jonkin niistä tai kaikki mainitut termit. Edelleen ohjelma lisäsi valinnaisia (ks. s. 4) termejä yhden kerrallaan siinä järjestyksessä, missä ne parhaiten selittivät mallia. Kunkin menoryhmän suhteellisia vaihteluita kokonaismenoista parhaiten selittävien yhtälöiden mallit on esitetty taulukoissa 1 ja 2.

Markkamääräisten kulutusmenojen tutkimiseksi kehitetyt yhtälöt on esitetty taulukoissa 3 ja 4 . -Ravintomenoja voitiin selittää muuttujan (X12 $\times$ X14) avulla suhteellisen hyvin, maanviljelijöiden kohdalla $69.7 \%$ ja palkansaajien kohdalla $75.4 \%$. Ravintomenojen riippuvuus kokonaismenoista ja ky-määrästä - palkansaajien kohdalla edellä mainittuun yhtälöön on lisätty termi $-0.483 \times 12 \cdot \times 14^{2}$, jolloin yhtälön selityskyky on $77.4 \%$ - esitetään taulukoissa 5 ja 6 . 
Koska heinä-syyskuun ravintomenot olivat korkeammat kuin vuoden muiden jaksojen, tutkittiin erikseen kulutuksen riippuvuussuhteita tänä ajanjaksona. Tällöin ilmeni, että ravintomenojen kasvu korkeampiin menoluokkiin tultaessa hidastui verrattuna vuoden muiden jaksojen vastaavaan kehitykseen.

Ravintomenoja lukuun ottamatta kaikki menoryhmät olivat ensisijaisesti riippuvia menoluokasta, vieläpä kasvoivat suhteessa menoluokan toiseen tai kolmanteen potenssiin. Menojen kohoamista hidastavana tekijänä esiintyi useimmissa tapauksissa ky-määrän tai lasten lukumäärän kasvu. — Ravintomenot osoittautuivat vähiten joustaviksi, niiden määrä lisäăntyi lineaarisesti menoluokan ja ky-määrän mukaan. Ravintomenoja joustavampia olivat vaatetus- ja maanviljelijöiden asunto- sekä palkansaajien muut menot. Niiden määrän vaihtelua menoluokan suhteen kuvaa paraabelifunktio. Joustavimmin tulojen mukaan vaihtelivat maaseudun palkansaajien asuntomenot sekä maanviljelijöiden ja palkansaajien kalusto- ja taloustarvikemenot. Maanviljelijöiden muut menot -ryhmä osoittautui myös varsin joustavasti tulojen (menoluokan) mukaan määräytyväksi. Nämå menoryhmät olivat lähinnä riippuvuussuhteessa menoluokan kasvamiseen kolmannen potenssin mukaan.

On kuitenkin todettava, että monet menoryhmät olivat käytellyn aineiston puitteissa sekä absoluuttisesti että suhteellisesti varsin pieniä. Tutkimusyksiköitä valaisevien tietojen (selittävien tekijōiden) perusteella ei sen vuoksi ole kaikilta osin voitu saada esille säännönmukaisuuksia, jotka selittäisivät näissä menoissa havaittavia vaihteluita. Sen lisäksi on tuloksia tarkasteltaessa muistettava, että kunkin ruokakunnan tiedot koskevat yhden kuukauden kulutusmenoja. Koska maanviljelijöille veroista aiheutuneet menot eivät jakautuneet tasaisesti eri kuukausille, on verojen huomioonottaminen menoluokkaa laskettaessa saattanut vaikuttaa eri tavoin eri ruokakuntien kohdalla. Tämän seikan korjaamiseen ei käytånnőn syistä ollut kuitenkaan mahdollisuuksia. - Toisaalta myös kulutusmenojen riippuvuussuhteita selvittävien muuttujien suhteen asetti käytettävissä ollut aineisto tietyt rajoitukset. 